\title{
Spectrum of giant cells and its significance on FNAC in breast lesions
}

\author{
Dayal $\mathrm{S}^{1}$, Mathur $\mathrm{M}^{2}$, Gupta $\mathrm{V}^{3}$ \\ ${ }^{1}$ Deparement of Pathology, UPUMS, Saifai Etawah, Uttar Pradehs, India \\ ${ }^{2}$ Department of Pathology, Government Medical college, Kannauj, Uttar Pradesh, India . \\ ${ }^{3}$ Department of Pathology, Jawahar Lal Nehru Medical college, Wardha, Maharastra, India.
}

\author{
Keywords: \\ Giant cells; \\ Fine needle aspiration \\ cytology; \\ Breast
}

\begin{abstract}
Fine needle aspiration of breast is being performed from last several years. It is not uncommon to find giant cell on FNAC of breast smears .Giant cells arises from monocyte / macrophage lineage which are capable of fusion to form multinucleated giant cell. The common giant cell seen in breast on fna smears are foreign body, Langhan's type, stromal giant cells, tumor giant cells and osteoclastic giant cell . It arises in benign as well as malignant lesions of the breast. Hence, their recognition and correct interpretation can be valuable to cyto pathologist who identifies the variation in diagnosis of pathology and to the clinician for the treatment modalities of different breast pathologies.
\end{abstract}

\section{INTRODUCTION}

Multinucleated giant cell in breast tissue were described originally by Rosen in $1979 .{ }^{1}$ Multinucleated giant cell have been described in several breast pathologies raising an interesting differential diagnosis. Multinucleated giant cell seen in breast on fna smears are foreign body, Langhan's type, stromal giant cells, tumor giant cells and osteoclastic giant cell. The causes of multinucleated giant cell includes: tuberculosis, leprosy, brucellosis, sarcoidosis, aspergillus, blastomycosis, coccidomycosis, histoplasmosis, actinomycosis, cat scrath disease and also may be due to

\footnotetext{
Correspondence:

Dr Seema Dayal, MBBS, M.D

Associate Professor, Department of Pathology

UPUMS, Saifai Etawah (U.P) India.

Email: seemadayal77@rediffmail.com
}

suture, silicon, breast implant, sub areolar abscess, duct ectasia along with idiopathic causes. ${ }^{2,3}$

\section{Langhan's giant cell}

Tuberculosis of breast is not uncommon in Indian set up. Clinically it may mimic carcinoma with lymph node metastatis because of presence of firm breast mass with enlarged node. Cytological examination of breast reveals granulomas, epitheloid cells, multinucleated giant cell of Langhan's type and caseous necrosis. ${ }^{4}$ The cytological features of granulomatous mastitis may also overlap. Noncaseating granulomas are also seen in sarcoidosis which may a create confusion because of possibility of confusion with other granulomatous lesions, a confirmation of diagnosis of tubercular mastitis is done by demonstration 
of acid fast mycobacterium tubercular bacillie and culture is advised. ${ }^{5}$

\section{Foreign body type giant cell}

Foreign body type giant cell is usually seen in fat necrosis, foreign body reaction. Fat necrosis is called as grandmother's disease because it is observed in grand mothers who sustain a trauma as a result of hugging their grandchild. It is clinically firm mass that is partially fixed to surrounding tissue, thus mimic carcinoma. On cytology it reveals amorphous material, fat, inflammatory cells, foreign body giant cell. But degenerated red blood cells conglomerate in high level of free fat released by necrotic adipocytes called myosphrulosis characteristic of fat necrosis on cytology. Foreign body type giant cell are also seen in foreign body reaction in which fragments of foreign bodies are seen along with inflammatory cells and necrotic material.

Sub areolar abscess begin as inflammation beneath nipple and progress to form abscess followed by sinus tract, drainage. Clinically it may present as nipple retraction, mass may be confused with neoplasm such as adenoma of nipple or carcinoma breast. It has some of potential diagnostic pitfalls for false positive diagnosis of malignancy but cytology examination reveals anucleated squamous cell, keratinous debris, cholesterol crystal, squamous epithelium strip, multinucleated giant cell, histiocytes.

\section{Stromal giant cell}

In fibroadenoma breast giant cells are rare. Stromal giant cell can be appreciated and rarely foreign body type giant cell can also be seen. The stromal giant cell fibroadenoma may be mis diagnosed with phyllodes tumor and metaplastic carcinoma. ${ }^{6}$ But the benign sheets of ductal epithelial cells and presence of naked nuclei confirm the diagnosis of fibroadenoma .

\section{Osteoclastic giant cell}

They are associated with invasive ductal carcinoma of breast. However, they are also associated with cribriform, tubular, squamous, papillary and mucinous carcinoma of breast. ${ }^{7,8}$ The diagnosis of osteoclast cell may be difficult on cytological examination as these cells can be bland in appearance and have similar appearance to foreign body giant cell associated with fat necrosis. ${ }^{7}$ Osteoclastic giant cell have positive staining for osteoclast markers, CD68, CD1a, tartrate resistance acid phosphatase .

\section{Tumor giant cell}

The tumor giant cells have nuclear features similar to the neoplastic ductal epithelial cells. These tumor giant cells were also positive for ER/ PR antigens similar to the ductal neoplastic cells as opposed to the osteoclast like giant cell which are negative for the same. A distinction should be made between these two as this has diagnostic and prognostic implications. There is less favorable outcome for patients with mammary carcinoma having osteoclast like giant cells when compared with conventional ductal carcinoma. ${ }^{9}$

\section{CONCLUSION}

It is not uncommon to find giant cell in breast smears on FNAC. Multi nucleated giant cells are found in inflammatory, benign and malignant lesions of the breast but their correct recognition and interpretation is must to diagnose the breast pathology so as to help the surgeon to provide accurate management to the patient.

\section{REFERENCES}

1. Rosen P. Multi nucleated mammary stromal giant cells. A benign lesion that stimulates invasive carcinoma. 1979;44:1305-8.

2. Koss L.G and Melamed M R. Breast. The text book of Koss's diagnostic cytology and its histopathologic bases. 5th ed. Walt kluwer, Philadelphia; 2005. pp1089-118.

3. Saad R, Silverman J. Breast. Text book of comprehensive cytopathology. Editor In: Marluce Bibbo and David Wilbur. 3rd edition, Elsevier, Philadelphia USA; 2008. pp718-54.

4. Lindholm K. Breast. Text book of Fine needle aspiration cytology editor in svante R Orell, Gregory F Sterett, Darrel Whitaker . 4th edition. Churchill living stone Elsevier Noida ( U.P) India . 2008. pp179-214 .

5. Anantha narayan R, Panikar J . Textbook of microbiology, in editor panikar J. Orient Longman Pvt ltd, 6th ed . Hyderabad, India; 2002. pp324-36.

6. N G WK. Fine needle aspiration cytology of fibroadenoma with multi nucleated stromal giant cells. A review of cases in a six year period. Acta Cytol. 2002;46:535-9. Crossref

7. Cai N, Koizumi J, Vazquez M. Mammary carcinoma with osteoclast - like giant cells . A study of four cases and a review of literature. Diagn cytopathol 2005;33:246-51. Crossref

8. Kurokawa K, Mouri Y, Asano A, et al . Pleomorphic carcinoma with osteoclastic giant cells of the breast. Immuno histochemical differentiation between coexisting neoplastic and reactive giant cells. Pathol Int. 2009;59:91-7. Crossref

9. Aganantis NT, Rosen PP. Mammary carcinoma with osteoclast - like giant cells: a study of eight cases with follow up data. Am J Clin Pathol 1979;72:383-9. Crossref 